\title{
Cartas de Nietzsche: Humano demasiado humano, educação e arte como construção de um pensamento original
}

\author{
Letters from Nietzsche: Human, all too human, education and art as \\ construction of an original thought
}

\author{
ENOCK DA SILVA PEIXOTO ${ }^{1}$
}

\begin{abstract}
Resumo: O período que daremos foco neste texto está restrito as cartas que Nietzsche escreveu dentre os anos de 1875 e 1879, quando ocorreu a elaboração e publicação da obra Humano, demasiado humano. Ela demarca o início das reflexões mais independentes do filósofo. Ele passou por um período de enorme sofrimento físico e pessoal: distanciou-se da atividade docente, rompeu com Wagner e Schopenhauer, tencionou sua relação com vários amigos e parentes. Situações que causaram enorme descontentamento, mas, foram fundamentais para o pensador produzir a sua obra, para encontrar a superação e recriar a própria vida. Veremos que a arte figurou para Nietzsche como meio formativo primordial, como fio condutor na educação de si mesmo e para confrontar o modo de vida gregário dominante em seu tempo.
\end{abstract}

Palavras-chave: Cartas. Arte. Educação.

Abstract: The period that we will focus on in this text is restricted to the letters that Nietzsche wrote between the years 1875 and 1879, when the elaboration and publication of the work Human, all too human, which marks, the beginning of reflections more independent of the philosopher. He went through a period of enormous physical and personal suffering: he distanced himself from teaching, broke up with Wagner and Schopenhauer, strained his relationship with several friends and relatives. Situations that caused enormous discontent, but, were fundamental for the thinker to produce his work, to find the overcoming and to recreate his own life. We will see art as a primary formative medium that figured as a guiding thread in educating oneself and to confront the gregarious way of life that was dominant in its time.

Keywords: Letters. Art. Education.

\section{Humano, demasiado humano: “periferia do próprio pensamento”}

O texto a seguir, com algumas modificações, integra a tese de doutorado com o título: As correspondências de Nietzsche e a educação em Assim falou Zaratustra: um processo de educação-estética. Nessa, analisamos a perspectiva artística e educativa que perpassam o pensamento de Nietzsche, tendo como base as correspondências que trocou com diversas pessoas dentre 1850 e $1888 .^{2}$

\footnotetext{
${ }^{1}$ Doutor em filosofia pela Universidade do Estado do Rio de Janeiro-UERJ; doutorando em filosofia pela Universidade Federal do Rio de Janeiro-UFRJ; mestre em educação pela Universidade Federal do Estado do Rio de Janeiro-UNIRIO; integrante como discente do Núcleo de Filosofias da Criação do Programa de Pós-Graduação em Filosofia da UFRJ (NFC-PPGF-URFJ/CNPq); professor de Filosofia da rede de ensino do Estado da Bahia. E-mail: enock-peixoto@hotmail.com.

${ }^{2}$ Nas cartas deste período seguiremos as publicações: NIETZSCHE, Friedrich. Correspondencia III Enero 1875 - Diciembre 1879. Traducción, introducción, notas y apéndices de Andrés Rubio. Editorial Trotta, Madrid, 2009 e Correspondencia IV Enero 188o - Diciembre 1884. Traducción, introducción,
} 
Menschliches, Allzumenschliches - Humano, demasiado humano, um livro para espíritos livres foi publicado em 1878 e demarca o rompimento com Wagner e Schopenhauer, por conseguinte, com a metafísica e romantismo de ambos. É a obra que inaugura, conforme muitos intérpretes e comentadores, a fase intermediária da filosofia de Nietzsche, onde o filósofo considera a necessidade de dissociar-se dos antigos mestres. Paulo César de Souza no posfácio ao livro começa reproduzindo: "Este livro é obra minha. Nele trouxe à luz minha mais íntima percepção dos homens e das coisas e pela primeira vez delimitei os contornos de meu próprio pensamento." Trata-se de um rascunho endereçado à Wagner e a esposa Cosima em 1878 que talvez não tenha sido enviado. De todo modo, evidencia a consciência de que aquele trabalho demarcava a sua autonomia intelectual. Mas é importante notar que a esta primeira edição ainda foram acrescidas outras duas: A primeira terminou em 1878, mas começou a ser produzida em 1876. No entanto, dentre os anos de 1879 e 1880 o filósofo complementou o projeto de Humano, demasiado humano com mais duas obras: Miscelâneas de opiniões e sentenças e $O$ andarilho e a sua sombra. Nessas, Nietzsche inaugurou a escrita em aforismos que veio a marcar as suas obras, há, então, uma mudança no estilo, claramente buscando dar forma artística ao seu texto. Quando anos mais tarde o filósofo elabora prefácios para os livros anteriormente publicados, tais obras são unificadas no volume intitulado Humano demasiado humano II.

A correspondência 673 a Ernst Schmeitzner apresenta o pedido de edição de Humano, demasiado humano: "Mas antes recebo o título inteiro do meu livro; isso será: Humano, demasiado humano: um livro para espíritos livres. Dedicado à memória de Voltaire no centenário de sua morte, 30 de maio de 1778." Este livro foi gestado em um período de grande sofrimento físico e a homenagem a Voltaire, alguém considerado por Nietzsche como autor de um pensamento autônomo, já é um indicativo do grau de independência do livro. Paulo César de Souza no posfácio que faz da obra ressalta:

Mas se este livro representou uma guinada, foi uma guinada dentro de um percurso próprio. É possível destacar temas e inquietações que o ligam às primeiras obras, e é evidente a continuidade entre ele e as obras posteriores. Abrindo Além do bem e do mal, publicado oito anos depois, verifica-se a mesma divisão em nove capítulos, e já nos títulos se revelam as afinidades dos seus conteúdos: metafísica, moral, religião e arte são os principais objetos da crítica nietzscheana, secundados por observações sobre política, sociedade,

notas y apéndices de Marco Parmeggiani. Editorial Trotta, Madrid, 2010. Estas são parte do conjunto das cartas do filósofo alemão publicado em seis volumes pela editora espanhola Trotta. Seguiremos o modo como os tradutores datam e numeram as cartas para delimitar as citações. 
personalidades, afetos, comportamentos, relações entre os indivíduos e entre os sexos. ${ }^{3}$

O livro é uma virada na obra de Nietzsche, sendo um marco para o filósofo construir e reconstruir seu pensamento. Era Nietzsche sentindo a urgência de constituir o próprio percurso filosófico e tudo indica que para fazê-lo a ruptura com os antigos mestres foi inevitável. Até a partitura de Tristão e Isolda que Nietzsche recebera de Wagner anos antes foi presenteada a Heinrich Köselitz (Carta 675): "Esta partitura trará muito mais frutos em suas mãos, meu querido amigo Köselitz, do que nas minhas: há muito aspirava a um proprietário e discípulo da arte mais digno do que sou no caso em que algo permaneceu nela da alma do grande homem que me deu." Nos primeiros dias de 1878 , conforme carta 676 a Richard Wagner e Cosima Wagner, Nietzsche mostra o significado de sua nova obra, o movimento que o impulsionou para a produção dela. Admite ter recorrido a pessoas e coisas, ou seja, elementos que de algum modo o moveram, tendo recorrido pela primeira vez "a periferia do seu próprio pensamento." Nos momentos de mais intenso tormento, o livro fora um consolo. Afirma o filósofo. "Talvez siga vivo porque fui capaz de escrevê-lo." Vejamos que mais uma vez a arte salvou a vida, se não fosse o impulso para criar, para sair de si e superar as limitações da doença, talvez ele tivesse sucumbido. Eduard Leuchtenberg Roon este fora o pseudônimo proposto por Nietzsche para a obra em questão que a princípio quisera que fosse anônimo, mas o editor Ernst Schmeitzner sugeriu o contrário, algo que acabou ocorrendo; o livro foi publicado com o nome do próprio Nietzsche.

A obra é fruto de um momento de dor, mas aponta para a superação de si: "Sinto-me como um oficial que assumiu um posto inimigo. Ferido sim - mas agora está ativo e - exibe sua bandeira. Sentindo mais felicidade do que dor, muito mais, por mais terrível que seja o espetáculo ao redor." As lutas feriram, mas ele lutou até chegar ao topo e erguer a bandeira como vencedor, quando a dor extrema é superada por ter conseguido ultrapassar mares revoltos. Esta vitória foi de uma tensão, sobretudo contra si mesmo, oriunda da difícil tarefa de não somente suportar a doença, mas ultrapassar os valores arraigados em si e estabelecer outros, de ter que deixar para trás amigos, princípios, formas de vida para instituir um estilo lídimo de estar no mundo. Tal perspectiva pode trazer a noção de que este embate do filósofo era fruto de alguém radicalmente ensimesmado, mas, além do que é meramente pessoal, ele sustenta ter o estranho sentimento de que não pensava de modo particular, mas coletivamente: "és uma estranhíssima sensação de sentimento de solidão e pluralidade.” Talvez nos ajude a entender esta afirmação a crítica de Nietzsche em carta posterior (678) a Reinhart von Seydlitz, que escrevera ao filósofo criticando o novo empreendimento de Wagner, a obra Parsifal. O músico enviara

\footnotetext{
3 NIETZSCHE, Friedrich. Humano demasiado humano: um livro para espíritos livres. Tradução, notas e posfácio de Paulo César de Souza. Companhia da Letras, São Paulo, 2005.
} 
uma cópia do livreto (Cf. notas 647-48) e Nietzsche apresenta sua impressão sobre a mesma: "Para mim, que estou tão acostumado ao grego, universalmente humano, considero tudo demasiado cristão, demasiado limitado no tempo; pura psicologia fantástica; nada de carne e demasiado sangue (a Eucaristia especialmente, é muito sangrenta para o meu gosto) [...]." O livro Humano, demasiado humano talvez tenha tido um caráter universal por estar próximo do grego, "universalmente humano" no qual prevalece a carne e não o sangue, ou seja, o mundo real, a terra, a vida. Além disso, é necessário reforçar que Parsifal tinha para Nietzsche uma característica demasiadamente cristã, se tornara uma obra catequética, voltada aos valores religiosos de um grupo restrito e não era uma voz que abarcava o mundo e todas as suas contradições. Conforme Jair Antunes: "E Nietzsche havia percebido que esta grande guinada ao cristianismo e à exaltação da alma alemã tinha como fundo o apoio do Estado à sua [de Wagner] arte nacionalista-cristã." 4 Logo, era uma arte a serviço da ideologia da religião e do Estado, contrário ao que ele valorizava nos gregos, por demonstrarem, que mesmo um empreendimento individual, um livro, oriundo de experiências demasiadamente próprias, devem expressar algo que extrapola o universo de cada indivíduo. Parece que podemos interpretar a partir desta questão, que nós somos linguagem do mundo e, como tal, a boa obra de arte pode manifestar e interpretar esta presença. “Todas essas belas invenções pertencem ao épico e, como eu disse, são projetadas para o olho interior. A linguagem soa como uma tradução de um idioma estrangeiro. Mas as situações e sua sucessão acaso não são altíssima poesia? Não é um último desafio para a música”? Este trecho é um comentário de imagens presentes no Parsifal como o Graal e o cisne ferido. Para Nietzsche, são linguagens místicas, pois traduzem outra dimensão, projetadas como uma espécie de iluminação religiosa. O esclarecimento de Maria Helena Lisboa contribui para esta interpretação:

A trama de Parsifal se baseia nas lendas do medievo sobre o Graal (o cálice sagrado que teria guardado o sangue de Cristo e a lança que o teria ferido), que se articula com a moral. Os personagens são claramente encarnados por preceitos de bem e mal: os cavaleiros do Santo Graal, guardiães das últimas relíquias cristãs, representam o reino do bem; o personagem principal, Parsifal, representa o herói casto que impregnado de paixão nega a sensualidade. ${ }^{5}$

\footnotetext{
${ }^{4}$ ANTUNES, Jair. Nietzsche e Wagner: caminhos e descaminhos na concepção do trágico. Revista Trágica: estudos sobre Nietzsche. V. 1, no 2, p. 53-70, 2008, p. 68.

${ }^{5}$ CUNHA, Maria Helena Lisboa. Nietzsche e Wagner: interpretação de um rompimento. In: Nietzsche e as cartas. Org: Marina Gomes de Oliveira, Rosa Maria Dias, 1 ed. Rio de Janeiro: Via Verita, 2019, p. 317.
} 
Nietzsche aponta então o contraste primordial com a peça wagneriana, como uma das razões teóricas do desacordo com o antigo mestre: a dissociação entre arte e vida. O mundo já é demasiadamente misterioso. Já está nele toda a expressão pela qual se pode tornar a existência arte, poesia. Sem a necessidade de se elaborar um universo imaginário, irreal, para justificar a nossa estadia no mundo. $\mathrm{O}$ desalento do pensador alemão fora com essa cristianização da arte, isso a tornava uma linguagem que não mais expressava a realidade em sua tensão constante, mas uma catequização que manifestava uma leitura específica do mundo, a cristã, relevante, mas é uma, dentre centenas de outras. O "inocente casto" capaz de trazer a salvação e curar as feridas soa como um desfecho idílico diante do aspecto trágico da vida, quando o filósofo quer afirmar exatamente a belicosidade do real. ${ }^{6}$

Na carta 709 a Ernst Schmeitzner de 14 de abril de 1878, Nietzsche faz algumas observações ao editor, entre estas quanto ao título: "Que as palavras 'demasiado humano' se destacam mais do que "Humano" é aconselhável por razões estéticas, no entanto, eu não gosto por razões racionais.” Parece que as duas outras expressões complementares à obra são um modo de evidenciar o teor principal do livro, que é destacar a demasiada humanidade ali presente, mas apenas por questões estilísticas isto deveria ser acentuado, pois humano deveria bastar. O problema parece ser os diversos adendos e equívocos no contexto da palavra humano, que acabam por distanciar do seu mais genuíno sentido, que para Nietzsche está associado à terra, aos problemas mais primordiais da existência.

Na carta 720, em 12 de maio de 1878 , Nietzsche se alegra da manifestação de Paul Rée sobre Humano, demasiado humano, algo que não aconteceu com outros colegas. Alguns apenas agradeceram sem fazer grandes comentários, outros criticaram entre si. Desse modo, a recepção não foi o que esperava (Cf. notas 70o, 701, 702). Jacob Burckhardt é considerado uma exceção, embora não haja nenhum testemunho conservado. De todo modo, existe um comentário em uma carta dele de 1878, na qual considera que nos livros de Nietzsche há sempre seu próprio ponto de vista "adquirido de maneira autônoma." Antes dessa afirmação o caracterizou como "um homem extraordinário". Esse reconhecimento talvez mostre com mais clareza a intenção nesta obra, na qual ele agora desenvolve pensamentos mais originais. Nietzsche lamenta em seguida a frágil recepção do livro entre os amigos, inclusive de Wagner e diante da afirmação de Rée do entusiasmo ao receber o conteúdo do livro e declara, repetindo palavras de J. Burckhardt: "Isto mesmo é o melhor que eu poderia esperar - estimular a produção de outros e o aumento da independência no

\footnotetext{
${ }^{6} \mathrm{O}$ conceito de trágico em $\mathrm{O}$ nascimento da tragédia e em toda a fase inicial da filosofia de Nietzsche, remete a duas divindades antagônicas presentes nas forças da natureza, mas, por um milagre grego, teriam se harmonizado e produzido a arte trágica- os deuses Apolo e Dionísio. Na maturidade, sobretudo após Humano, demasiado Humano, trágico, assim como a concepção geral de arte está diretamente associado à vida, ao modo como a damos forma, contorno; assumindo as suas manifestações mais belas e mais terríveis como dignas de afirmação.
} 
mundo." O papel da obra de Nietzsche, que ele deliberadamente aceita como seu, é educativo. Estimular outros para serem criadores, que saibam elaborar os seus próprios itinerários existenciais, o que ampliaria a independência.

Em 16 de junho de 1878 (carta 727), Nietzsche escreve a Erwin Rohde, em resposta a uma carta na qual esse se admirara (KGB II/6, 894), da mudança de estilo drástica do amigo e da incrível semelhança com a obra de Paul Rée: A origem dos sentimentos morais. A nota 716 traz também o estranhamento de Malwida, ela escreve que Nietzsche não era analítico como Rée, por isso ele deveria criar artisticamente. A mudança de foco, a fase que os intérpretes denominam como positivista ou intermediária ${ }^{7}$ iniciava, mas é curiosa a questão que os amigos apontavam, ou seja, a perspectiva artística no modo de produzir do filósofo. Críticas às quais ele responde:

A propósito: sempre busque somente por mim no meu livro e não ao amigo Rée. Tenho orgulho de ter descoberto suas magníficas qualidades e aspirações, mas ele não teve a menor influência na concepção de minha "filosofia in nuce": esta estava pronta e em boa parte confiada ao papel quando o conheci mais intimamente no outono de 1876. Estamos localizados em um mesmo nível: o prazer de nossas conversas foi imenso e o benefício para ambas as partes foi, sem dúvida, muito grande, tanto que Rée, com gentil exagero, me escreveu em seu livro (A origem dos sentimentos morais): "Ao pai desta escrita, com agradecimento, sua mãe".

O autor de Humano, demasiado humano tem admiração pelo talento de Rée, mas admite que não sofrera influência daquele e sugere que o que ocorreu foi o contrário ao citar uma frase de Rée na qual admite que o livro fora inspirado em formulações de Nietzsche e, por isso, o considerava pai do mesmo. Esta metáfora da gestação está relacionada à criação a partir de si mesmo, de nossos impulsos mais íntimos. Mas embora ele seja "a mãe", quem deu forma a obra, a fez vir à vida, teve como inspirador, como colaborador, alguém que depositou o germe gerador para que ela emergisse. Sendo assim, houve uma simbiose na construção de ambos os livros, tanto Nietzsche, quanto Rée influenciaram na obra um do outro.

Após lamentar com o editor Ernst Schmeitzner (carta 728 de 20 de junho de 1878), de Wagner decidir não publicar mais em sua editora, Nietzsche mostra certo contentamento por seu livro ter sido publicado em um momento tão tenso na Europa: "Porém, não quero esconder que abençoo de todo o coração a publicação do

\footnotetext{
7 Como comentamos na nota 110 existem intérpretes da filosofia de Nietzsche que dividem a sua produção filosófica em três momentos. A denominada "metafísica de artista", voltada para a metafísica da arte; a "positivista" que valorizou uma ciência fundada na arte e o período da maturidade, no qual estabelece o seu pensamento original. Em Scarlett Marton (1990) encontramos esta posição.
} 
meu livro espiritualmente livre e luminoso, numa época em que nuvens negras se acumulam no céu cultural da Europa e a intenção obscurantista é quase moralidade." O obscurantismo que se tornava algo quase moral assustava o filósofo e o seu livro estava na contramão dessa tendência. $O$ escrito servira como uma espécie de tônico que fizera se sentir melhor, além disso, ele explicita que através dele se esforçou para dar passos autônomos na sua produção intelectual. "Em geral e nos mínimos detalhes: agora ouso recorrer por conta própria o caminho da sabedoria e ser eu mesmo filósofo; antes eu venerava os filósofos." As afirmações anteriores demarcam um momento decisivo da filosofia de Nietzsche, ele admite que a partir de Humano, demasiado humano ocorreu o início de sua própria perspectiva. A veneração aos filósofos que ele interpreta como um caminho da sabedoria passa a ser estabelecida a partir dele mesmo. Na carta de 15 de julho de 1878 (carta 734) para Mathilde Maier, destaca a perplexidade da amiga sobre o seu livro. Ela escrevera que ficou dias com insônia por conta de tal leitura. Dentre as questões que ela destaca (Cf. nota 730), está a concepção da metafísica como ilusão. Ela discorda dessa tese, mas elogia o que denomina de "multidão de observações sutis”, e que superavam qualquer perplexidade. Na mesma correspondência emergem mais críticas diretas às obras de Wagner. Nietzsche associa a arte do músico à arte barroca, avaliando-a como uma excitação excessiva:

Aquele ofuscamento de tudo o que é verdadeiro e simples, a luta com a razão, contra a razão, que quer ver em todas e cada uma das coisas um milagre e um absurdo- além de uma arte barroca de super-excitação e a glorificação do excesso plenamente acordes- me refiro à arte de Wagner- essas duas coisas foram o que me deixaram cada vez mais enfermo, e quase me afastaram do meu bom temperamento e do meu talento.

Notemos que se trata de uma crítica ao excesso, ao esforço de esconder pela arte aquilo que o real é. Possivelmente uma referência ao inocente jogo da natureza que atua sem necessidade de interpretações milagrosas ou absurdas. Ela já teria, entendemos que pode ser a concepção de Nietzsche, a força do milagre: por criar sempre a partir de si mesma na sua robustez de construção e desconstrução constante. O filósofo admite que este falseamento o deixou mais enfermo, afirmação que frisa mais uma vez: certa manifestação da arte tem o poder de causar saúde ou enfermidade, não somente o seu corpo individual era afetado, mas também os reflexos artísticos não edificadores presentes na cultura. A arte pode funcionar como remédio ou como veneno para a saúde social. Nesse momento, Nietzsche interpretava que a música de Wagner era como um vírus que penetrava negativamente nas entranhas sociais e sustenta ter passado por uma transformação; conseguia viver como os homens que habitam na neve dos vales precisando de grande resistência para tal. Mais uma vez aponta os gregos, mais do que nunca, como seus guias. Assim, buscava a sabedoria grega para entender que situações de 
calmaria, de regularidades e irregularidades sempre ocorrerão. Era preciso buscar o que lhe pertencia e, para isto, a solidão era uma companheira necessária: "Agora abalo tudo o que não me pertence, pessoas, amigos e inimigos, costumes, comodidades, livros. Viverei em solidão por anos até que seja lícito (e provavelmente necessário) me relacionar novamente, já maduro e preparado, como filósofo da vida." Ser filósofo da vida era uma exigência que demandava tempo, além de se afastar de tudo que até então tinha valor. Tais elementos (amigos, inimigos, comodidades...), serviram para formar determinados hábitos, determinada percepção, exigindo, assim, estabelecer distanciamento não somente físico, ou seja, tornar-se um ermitão, mas quanto aos valores, diante da constituição cultural.

Um filósofo da vida, entre outros atributos, é aquele que tem a força para ser adepto de si: "Veja você que alcancei um grau de sinceridade tal que suporto apenas as relações pessoais mais cristalinas. Evito as meias amizades e os partidarismos, não quero partidários. Que todos (e todas) possam ser partidários unicamente de si mesmos!" Ser partidário de si significa tornar-se um maestro que toma a batuta da própria vida e consegue colocá-la em harmonia, mesmo contra todos os tons dissonantes. Entendemos que ser filósofo da vida é exatamente este esforço em dar um sentido singular ao existir. É uma educação pela arte que permita recriar a vida pela vertente peculiar dos indivíduos e isso somente cada um pode fazer por si.

Conforme o que atesta a carta 795 a Ernst Schmeitzner de 12 de janeiro de 1879, Nietzsche faz várias observações ao editor sobre trechos de seu novo livro Opiniões e sentenças várias, a segunda parte de Humano, demasiado humano. Após propor as mudanças que pretendia em frases do livro, pede que seja incluída em qualquer parte uma das sentenças pela qual sentia mais orgulho: "O que é a genialidade? - Querer um objetivo elevado e os meios para alcançá-lo." Importante desta reivindicação é que antes ele fizera observações bem precisas, que certa frase deveria estar colocada antes e depois da outra, mas no caso específico desta, exatamente daquela que sentia mais orgulho, o lugar era indiferente. Parece que isso revela que as orações realmente relevantes podiam ser colocadas em qualquer lugar, pois a compreensão dela dependeria de quem as lê. Outra questão consiste na definição clara do que é a genialidade. Ter um fim elevado e os meios necessários para alcançá-lo. Aqui o significado de gênio difere da interpretação da fase do jovem Nietzsche, quando o conceito era entendido como fruto espontâneo da natureza, embora as condições para o seu emergir pudessem ser criadas por uma educação para uma cultura elevada. Aqui, diferentemente, o caminho do gênio podia ser construído. Talvez por isto o filósofo valorizasse tanto a importância de cada um ter uma tarefa. ${ }^{8}$

\footnotetext{
${ }^{8}$ Encontraremos esta concepção de gênio como um milagre fortuito da natureza, por exemplo, em $O$ futuro de nossos estabelecimentos de ensino, 2003.
} 


\section{A arte musical como percurso educativo}

Na carta 797 à mãe Francisca e à irmã Elisabeth, Nietzsche novamente alude à Segunda parte de Humano, demasiado humano e a constante ajuda de Heinrich Köselitz na correção de seus trabalhos: "Em poucas semanas, Schmeitzner publicará algo meu, um apêndice do último livro, de quase 150 páginas, está sendo impresso em um bom ritmo, Köselitz (em Florença) corrige as anotações novamente." A carta 799 a Köselitz contém a alusão ao período em que Nietzsche, em agosto de 1878 passou por Oberland Bernés, Grindelwald e Interlaken. Nestas altas e belas montanhas compôs a maior parte de seu novo livro: "Foi pensado e escrito em sua maior parte a uma altura de 7.20o pés acima do nível do mar. É talvez o único livro no mundo de tão alta procedência. - Agora você pode rir"! Embora ele aborde ter escrito e pensado boa parte de Humano, demasiado humano nas alturas de forma jocosa, este episódio não deve ser dissociado do valor que o filósofo atribuiu à relação pensamento e natureza e à dicotomia altura e planície. As alturas são o lugar onde se constrói pensamentos elevados, acima da singeleza da planície. Estas formulações aparecerão também no Zaratustra, como no prólogo, por exemplo. A planície é o lugar comum, que abafa a singularidade, que quer tornar todos iguais. É baixo por não elevar ao que as alturas têm de mais valoroso: provocar o ato criador, incitando a elaboração de novos modos de existência. Acena ainda, na mesma carta comentada acima, para as muitas dores que sentia, diante das quais vivia como um "autêntico santo", mas não um santo subserviente às normas eclesiais, pois acrescenta: "Mas com a mentalidade de Epicuro completamente proscrito - muita paz de espírito e paciência e contemplando a vida, apesar de tudo, com alegria." No aforismo 192 de $O$ viandante e sua sombra, por exemplo, escreve: "Um pequeno jardim, figos, porções de queijo e três ou quatro bons amigos-esta foi a opulência de Epicuro"9. O filósofo grego defendia que todos os bens deveriam ser apreciados comedidamente, assim, poder-se-ia desfrutar plenamente desses prazeres, pois eles refletem a bondade da natureza. A concepção epicurista está em avaliar os aspectos bons e nocivos da existência e, apesar destes, viver com leveza e paciência; a autarquia sem o controle de forças externas atingiria a ataraxia, a imperturbalidade, serenidade diante das adversidades que a vida apresenta ${ }^{10}$. Ao fazer da filosofia não somente um método de reflexão sobre o real ou instrumento crítico para pensar as diversÇas circunstâncias, Nietzsche buscava o filosofar como modo de vida. Assim como o mestre grego da Antiguidade se sentia um proscrito,

\footnotetext{
9 NIETZSCHE, Friedrich. Humano, demasiado humano II, § 192.

${ }^{10}$ Cf. EPICURO. Antologia de textos de Epicuro. Coleção: Os Pensadores. São Paulo, Nova Cultural, 1988.
} 
mas com alegria, este era o preço a pagar por questionar com a própria vida os hábitos prevalecentes em sua época.

Na missiva 819 ao editor Ernst Schmeitzner, em 14 de março de 1879, Nietzsche mostra irritação por ele ter publicado fragmentos de suas correspondências, além de um apêndice acrescido pelo editor como publicidade ao final de Humano, demasiado humano II. Além de erros de impressão no livro. Atentemos para a observação do filósofo: "Dois erros de impressão inconcebíveis, apesar da minha expressa correção: o infame disparate "muito seguro" (em lugar de "mais seguro") e o tolo "verdadeiro" (por "nutritivo"), que leva a perder a força do toda a passagem." Esses equívocos estavam nos aforismos 356 e 223 e interessa para a nossa argumentação a preocupação do filósofo com a força do texto. $\mathrm{O}$ enfado com o editor sobre a inobservância na utilização de termos, que modificavam a perspectiva que ele pretendia, estava no contexto de sua preocupação com o estilo, em tornar o seu trabalho estético. Na missiva 833 a Heinrich Köselitz perdura o tema: "Estou refletindo sobre o estilo. Por favor, escreva-me para meu uso e proveito algumas teses sobre o meu estilo atual (você é seu único conhecedor) - acerca do que sou capaz e o que não sou capaz [...]. Devemos ajudar-nos a sermos melhores, para fazer as coisas cada vez melhores." Köselitz conhecia escrita de Nietzsche, inclusive por corrigir os seus textos, mas, atentemos para o importante detalhe dele ser um artista. Embora não explicitado neste momento, parte da preocupação do filósofo alemão estava também em se colocar sob julgamento da batuta de um músico, que conhecia e reconhecia o estilo poético dele e em que medida o seu trabalho reverberava arte.

A correspondência 846 a Carl Burckhardt escreve sobre a necessidade de deixar definitivamente a função docente, tendo como motivo alegado a sua enfermidade e os efeitos colaterais dela:

Sr. Presidente: $\mathrm{O}$ estado de minha saúde, por cuja causa eu já lhe enviei uma petição em mais de uma ocasião, faz-me dar o último passo hoje e expressar o pedido de que me seja permitido retirar-me de meu cargo como docente na Universidade. As dores de cabeça, que aumentam até se tornarem extremas, as crescentes perdas de tempo que sofro de ataques de dois a seis dias, a diminuição considerável da minha faculdade de visão foi recentemente constatada [...].

Embora ainda hoje, não haja clareza e objetividade diagnóstica sobre a enfermidade principal que assolava Nietzsche, é certo que ele passara por períodos de grande sofrimento. A dor de cabeça era constante, tanto que nesta mesma carta pergunta se ainda teria algum dia sem passar com aquela companheira indesejada. A Marie Baumgartner em 7 de maio de 1879, anuncia o abandono da cátedra e que em breve abandonaria Basiléia também. A debilidade não era apenas física, mas vinha 
da sua produção teórica também. O livro que o filósofo escrevera com todo entusiasmo e, para o qual, esperava um retorno positivo, ficou muito distante da expectativa. Conforme carta 857 a Franz Overbeck, lamenta ter vendido apenas 120 dos 1000 exemplares que esperava, mas nem tudo era notícia ruim. Na carta 868 para sua irmã, aborda ter recebido um valor maior que o anteriormente estabelecido pelas autoridades de Basiléia como rendimento da atividade docente: "Overbeck acabou de me comunicar que a boa Sociedad Académica me designou outros 1.000 francos por seis anos. Com o qual a soma da pensão ascende a 3.0oo francos."

$O$ viandante e sua sombra fora o segundo e último apêndice de Humano, demasiado humano. No momento em questão era um manuscrito da mesma época da carta 880 a Heinrich Köselitz de 11 de setembro de 1879, enviada no mesmo ano. Nietzsche chegara aos 35 anos e reflete como este momento marcava a metade de sua vida; sobre a obra que terminava afirma: "Agora me sinto a respeito como o mais velho dos homens; mas também porque completei o trabalho da minha vida. Uma boa gota de azeite foi derramada através de mim, isso eu sei, e não será esquecida. No fundo, eu já fiz a prova de minha concepção de vida: muitos mais a farão."

O filósofo tinha consciência de que a sua obra reverberaria em várias consciências. Completar o que ele, nesse momento, denominou de trabalho da vida, causou cansaço, sensação de velhice, mas trouxe efeitos nefastos. Estava inaugurado o Nietzsche da maturidade, que ousava formular pensamentos com os quais testava a sua concepção de vida. Eis um prisma que denota a intenção educativa da obra em questão, o azeite (as suas ideias) fomentaria o desejo de outros indivíduos serem instigados por elas. No entanto, na continuidade da carta há um enfoque específico da educação nietzschiana: declara não estar com os ânimos abatidos e se perguntara de onde vinha tal força; concluindo que não era dos homens, pois estes se escandalizaram com ele, salvo algumas exceções. Notemos: o contexto da carta sustenta a noção de esforço, de superação, de luta, de ultrapassar diversas dores para atingir uma meta. Essa postura altiva não é compreendida por muitos seres humanos, quando ele afirma que a sua o impulsionou a criar em um cenário totalmente adverso. Ele está pensando, é provável, no homem gregário, absorvido por uma cultura decadente, que pensa e age conforme a maioria, movida por comportamentos padronizados. Mas existem aqueles que compreenderam a sua busca: as poucas exceções. É para estes sua concepção educativa se destina. Ainda sobre a obra antes citada propõe ao amigo a leitura para ver se encontraria algum resquício de sofrimento e angústia. Ele pensava que não, pois: "essa crença já é um sinal de que nessas opiniões deve haver forças ocultas e não desbotamento e cansaço; é o que buscarão todos quantos aqueles que têm antipatia por mim."

Apesar da previsão de que os seus contemporâneos leriam de forma negativa o livro, sente dele brotar força e não esmorecimento, oriundo do que denomina "forças ocultas". O conjunto de seus textos permite avaliar como a força fisiológica que o movia e permitia superar as adversidades. Ser caminhante e não poder fugir 
de si, eis o que parece querer apontar com o título do livro. Precisamos encontrar modos de vida adequados, apesar de nós mesmos. É possível fugir de muitas coisas, de pessoas, de situações, de lugares, mas de si mesmo não é. Diante da inevitabilidade de se distanciar da própria sombra, a única saída é caminhar pelos percursos da existência, preferencialmente dando forma ao próprio destino. Viver é uma decisão sobre o melhor modo de estar consigo mesmo.

Para o editor Ernst Schmeitzner, na missiva 915 em 18 de dezembro de 1879, Nietzsche escreve: "Considero algo quase incrível que $O$ caminhante tenha terminado “Toda a 'Humanidade' com os dois apêndices nasceu nos tempos de dores mais intensas e incessantes- e, contudo, me parece uma criatura plena de saúde. Este é o meu triunfo." Eis uma comprovação do que apontamos até então: que toda a obra Humano, demasiado humano e os dois apêndices são frutos de um esforço imenso, de um trabalho constante de superação. Oriundo de um corpo doentio, mas o seu conteúdo era saudável. Nesta afirmação percebemos o distanciamento da filosofia de Schopenhauer, para quem o sofrimento se tornou a base do seu pensamento. Conforme Georg Simmel “[...] a unidade da existência é vontade. A partir daí Schopenhauer deduz o caráter de toda a vida e observa a harmonia e a ordem do mundo dos fenômenos." "1 Em Nietzsche não há um lugar a partir do qual se possa pautar o ordenamento fenomênico, ele demonstra que "há alegria no trágico". Neste contexto interpretativo, Miguel Angel de Barrenechea, ao analisar a concepção trágica grega seguindo a leitura de Nietzsche, afirma: "A tragédia permite dizer sim à vida até nos seus mais profundos sofrimentos; na exaltação da dor e da morte é comemorada a inesgotabilidade da própria existência, até aceitar e celebrar o sacrifício de todos os existentes." ${ }^{12}$ A dimensão tenebrosa da vida pode ser, de algum modo, transposta pela criação; não se trata de transformar a dor em alegria, de amenizar o seu aspecto conflituoso, mas de perceber que no fundo de todas as coisas há algo belo, intenso, vital que pode manifestar-se pela criação. $\mathrm{O}$ estético para Nietzsche não está somente na manifestação da beleza, na pergunta sobre o gosto, ou o sentimento racional ou sensível na percepção artística. Estético é conseguir dar forma ao caos da existência, ao seu aspecto de constante fruição, é uma modo de dar harmonia à desordem do mundo.

As correspondências dos anos 1880 e $1884,{ }^{13}$ começam com a carta a Otto Eiser, médico que havia cuidado de Nietzsche, na qual acena para o seu constante padecimento, mas apesar da aflição apresenta algo propositivo. A carta 2 deste

\footnotetext{
"SIMMEL, Georg. Schopenhauer e Nietzsche: Tradução de César Benjamin. Rio de Janeiro, Contraponto, 2011, p. 63.

${ }^{12}$ BARRENECHEA, Miguel Angel de. Nietzsche e a alegria do trágico. Rio de Janeiro, 7 Letras, 2014, p. 39 .

${ }^{13}$ Nas cartas seguintes utilizaremos a publicação: NIETZSCHE, Friedrich. Correspondencia IV Enero 1880 - Diciembre 1884. Traducción, introducción, notas y apéndices de Marco Parmeggiani. Editorial Trotta, Madrid, 2010.
} 
período destaca novamente o pressentimento da morte, quando ele escreve para a amiga Malwida von Meysenburg, sustentando que os sintomas mostravam que essa estaria próxima. Ele afirma que nos seus vários anos de enfermidade aprendera a ser um asceta sem necessidade de religião ou arte. Orgulhava-se de sua obra e tinha consciência de ter jogado a muitos "uma gota de bom azeite e que eu tenho dado a muitos uma indicação até a autossuperação, o caráter pacífico e o senso do justo." Além disso, ele destaca o valor da vida como meta fundamental pela qual vale a pena afirmar a vida, apesar do sofrimento: "Nenhuma dor tem sido capaz, nem deveria ser, de me dizer para dar um falso testemunho sobre a vida, tal como eu a conheço." A dor não deve ser motivo para negar a vida, mas para defendê-la; notemos que esta posição não ocorrera em um momento de paz, mas surgia na turbulência do sofrer cotidiano e remonta a antes citada autossuperação como educação de si.

Com a mãe e a irmã reporta-se ao amigo Köselitz (carta 109), retomando o constante debate sobre a arte. Todas as ocupações e estudos do filósofo não prescindiam do problema estético e mais do que caracterizar a arte como um elemento a mais para interpretar a vida, o filósofo a compreendia como uma grande potência criadora. Mas especificamente, Nietzsche lembrada música do amigo, a ópera cômica Brincadeira, astúcia e vingança que é também o título que encabeça os aforismos iniciais de A gaia ciência. Ele antes desconhecia a ópera e a considera música de primeira ordem, que criava um tipo de arte adequado a sua filosofia. Notemos a proximidade entre filosofia e literatura. Um estilo musical que se adéqua a uma filosofia? É evidente o objetivo de Nietzsche que visava elaborar um modo de pensar e redigir que não prescindisse do aspecto estético. Se Wagner fora a grande inspiração em um momento anterior, neste, era Köselitz que dominava o interesse musical dele. A carta 110 a Franz Overbeck retoma o elogio à ópera anteriormente citada e nesse momento aponta mais elementos interpretativos: ela entusiasmava por sua nova e especial beleza, continha jocosidade, graça, enorme gama de sentimentos, profundidade, uma inocente alegria e cândida elevação, além disso, devotava perfeição técnica e refinamento. O filósofo sustenta que sua filosofia encontrara nesta música "a intercessora mais melodiosa". Nesses argumentos percebemos outros detalhes do que ele considera essencial na ópera do amigo; elementos que se vinculam com a sua filosofia. Ou seja, Nietzsche parece elaborar um "pensamento artístico", não apenas no conteúdo, mas também na forma e essa última teria a musicalidade como norte.

Na carta 140, Nietzsche recebe uma observação de Overbeck sobre Aurora $^{14}$ e reproduz o que o outro amigo escrevera para Köselitz. O livro infundia enorme

\footnotetext{
${ }^{14}$ Livro publicado em 1881, Morgenröte, integra a tríade, junto com Humano, demasiado humano e $A$ gaia ciência, das obras a partir das quais Nietzsche assume um percurso filosófico próprio. Composto por 575 aforismos é avaliado por Nietzsche no capítulo de Ecce Homo a ele dedicado: "Com este livro começou a minha campanha contra a moral". Não vamos adentrar no debate se o livro é apenas uma preparação para as obras da maturidade mas essa menção do filósofo ao tema da moral indica que
} 
ânimo de vida por estar impregnado da profunda e sincera convicção de que a missão da verdade não é produzir consolo. $\mathrm{O}$ pensador considera significativa a frase e a denomina como digna de um Sancho Pança. Possivelmente, por este personagem de Cervantes, que apesar de seguir as loucuras de Dom Quixote, figurava como a consciência daquele, já que de certo modo, o acordava para uma realidade que não era ilusória. Diferente do que ocorreu na história da filosofia, quando a verdade foi entendida como um alívio, uma estabilidade para tornar a vida possível, o livro indicava, portanto, que ela não é nenhuma forma de consolo. Talvez possamos falar de alívios que ajudam a torná-la viável de ser vivida, como a música. Na mesma correspondência o filósofo cita Emma Wixon, uma cantora de ópera celebrada na época e comenta tê-la ouvido duas vezes, descrevendo a experiência como "uma doce embriaguez e que nenhuma voz teve tanto poder sobre ele: "Talvez eu me encontrasse ainda pior se não tivesse ouvido! As coisas boas são remédio para mim"! A arte tinha efeito curativo, alívio objetivo para as angústias vivenciadas. A frase anteriormente citada está no contexto de uma nova descoberta feita pelo filósofo que marcara decisivamente a sua vida: o contato inicial com a ópera Carmem de Georges Bizet. Para ele, essa obra era plena, intensa, emocionante e em nada lembrava Wagner. Os franceses, segundo Nietzsche, teriam dado direção mais adequada à música dramática, pois a paixão nunca era artificial. Ouvir opera era algo benévolo e por isto funcionou como medicina e a paixão que a música transmitia, conforme a tradição francesa, na interpretação de Nietzsche, não era artificial. O filósofo, assim como os gregos antigos, não tratava a arte como representação apenas; ela deveria expressar a intensidade da vida. A carta 174 retoma a interpretação de Carmem, entendendo-a como manifestação de saúde. O filósofo, após lamentar a Köselitz a morte de Bizet, elogia a paixão que a ópera irradiava e reitera estar bastante doente, contudo, se sente reconfortado, graças à ópera. Esta aparenta ser uma alegação banal, mas o filósofo estabelece uma clara associação entre um corpo que responde de forma saudável às questões que envolvem a vida, movido pela arte musical.

Os temas retratados neste texto foram diversos, mas quisemos, sobretudo, focalizar a obra Humano, demasiado humano como marco inicial pelo qual Nietzsche inaugura a sua própria filosofia. O livro em questão é apontado como aquele em que pela primeira vez ele recorreu a "periferia do próprio pensamento." Ele foi produzido em um momento de dor, mas aponta para a superação de si. Foi necessário romper com modos de vida, influências filosóficas e artísticas, para

esse livro é primordial na constituição da filosofia madura de Nietzsche. Concordamos com os intérpretes que o consideram como despertar para uma nova perspectiva de sua filosofia. "Aurora, como o título sugere, é uma espécie de despontar de novas auroras em sua filosofia ou, em outros termos, que tal livro figura como o delicado rubor de um novo amanhecer, querendo com isso indicar certa mudança em sua filosofia" (Geraldo Dias: Aurora: uma virada metodológica na filosofia de Nietzsche. Seara Filosófica, N. 9, Verão, 2014, p. 219). 
estabelecer um percurso como partidário de si mesmo. Dentre outros aspectos que trabalhamos, ser partidário de si resume adequadamente um caminho de afirmação, perpassado pela arte e pela educação. Salientamos que o tema pedagógico, diferente do que ocorreu na primeira fase da filosofia de Nietzsche quando ele abordou diretamente questões institucionais, sobretudo sobre o ginásio as universidades, agora a formação perpassa pela necessidade de construção de si. O tema da formação humana perpassa implicitamente as cartas e os livros e, no nosso entendimento, não pode ser pensado sem considerar a função da arte, sobretudo a musical, como elemento necessário para constituir uma presença autônoma e criativa no mundo.

\section{Referências}

ANTUNES, J. “Nietzsche e Wagner: caminhos e descaminhos na concepção do trágico”. In: Revista Trágica: estudos sobre Nietzsche. v. 1, no 2, p. 53-70, 2008, p. 68.

BARRENECHEA, M. A. Nietzsche e a alegria do trágico. Rio de Janeiro: 7 Letras, 2014.

BURCKHARDT, J. Reflexões sobre a história. Tradução de Leo Gilson Ribeiro, Rio de Janeiro: Zahar Editores, 1961.

. Cartas. Seleção e edição de Alexandre Dru. Tradução de Renato Rezende, Rio de Janeiro: Topbooks, 2003.

CERVANTES, M. Don Quijote de la Mancha. Trad. de Viscondes de Castilho e Azevedo. São Paulo: Abril, 1978.

CUNHA, M. H. L. Nietzsche e Wagner: interpretação de um rompimento. In: Nietzsche e as cartas. Org: Marina Gomes de Oliveira, Rosa Maria Dias. Rio de Janeiro: Via Verita, 2019.

DARWIN, C. A origem das espécies. 3a ed. São Paulo. Martin Claret, 1859.

DIAS, G. Aurora: uma virada metodológica na filosofia de Nietzsche. Seara Filosófica, no 9, Verão, 2014.

DIAS, R. M. e OLIVEIRA, M. G. Nietzsche e as cartas. Rio de Janeiro: Via Verita, 2019.

EPICURO. Antologia de textos de Epicuro. Seleção de textos: José Américo Motta Pessanha Traduções e notas: Agostinho da Silva, Amador Cisneiros, Giulio Davide Leoni, Jaime Bruna. São Paulo, Nova Cultural, 1988 (Coleção Os Pensadores).

JANZ, P. C. Friedrich Nietzsche. 4 vols. Trad. Jacobo Muñoz. Madrid: Alianza, 1987.

MARQUES, A. "No fundo sou todos os homens da história": Nietzsche: Os vinte anos fundamentais a partir de suas cartas. Círculo de Leitores, 1996.

MARTON, S. Nietzsche: das forças cósmicas aos valores humanos. São Paulo:

Brasiliense, 1990.NIETZSCHE, F. Digitale Kritische Gesamtausgabe von Nietzsches Werken und Briefen. Edição organizada por Paolo D'Iorio, baseada na edição crítica de G. Colli e M. Montinari e publicada pela Nietzsche Source. Edição eletrônica. Acesso em 01/o4/2020.

2001.

. A gaia ciência. Tradução Paulo César de Souza. São Paulo: Companhia das Letras,

. Sobre os nossos estabelecimentos de ensino. Escritos sobre educação. Tradução, apresentação e notas de Noéli Correia Sobrinho. Rio de Janeiro: Ed. PUC-Rio; São Paulo, Loyola, 2003. 
Humano demasiado humano: um livro para espíritos livres. Tradução, notas e posfácio de Paulo César de Souza. São Paulo: Companhia da Letras, 2005.

. Correspondencia III Enero 1875 - Diciembre 1879. Traducción, introducción, notas y apéndices de Andrés Rubio. Madrid: Trotta, 2009.

. Assim falou Zaratustra, um livro para todos e para ninguém. Tradução de Mario da Silva. 18. ed. Rio de Janeiro: Civilização Brasileira, 2010.

. Correspondencia IV Enero 1880 - Diciembre 1884. Traducción, introducción, notas y apéndices de Marco Parmeggiani. Madrid: Trotta, 2010.

ROUX, W. La lutte des partiesdans l' organisme.Trad.L. Cohort, S. Danizet-Bechet, A.-L. Pasco-Saligny et C. Thébault. Paris: Matériologiques, 2012.

SAFRANSKI, R. Nietzsche: biografia de uma tragédia. Tradução de Lya Luft. São Paulo: Geração Editorial, 2001.

SIMMEL, G. Schopenhauer e Nietzsche: Tradução de César Benjamin. Rio de Janeiro, Contraponto, 2011.

WAGNER, R. Beethoven. Dichtungen und Schriften, vol. IX.Ed.de Dieter Borchmeyer. Frankfurt am Main: Insel, 1983.

Submissão: 24. 10. 2020 / Aceite: 15. 01.2021 